\title{
TINJAUAN \\ AL-QUR'AN TERHADAP NIKAH BEDA AGAMA MEMAHAMI Q.S. AL-BAQARAH AYAT 221
}

\author{
Syaiful Ilmi
}

\begin{abstract}
ABSTRAK
Nikah beda agama dapat ditetapkan dengan pendekatan maqashid al-syar'i. di mana salah satu poin dalam maqashid al-Syar'i adalah hifdz al-nasab. Dengan kembali menimbang, bahwa maqashid al-Syariah sebagai tujuan yang dikehendaki oleh syari'at, sebagaimana pernyataan Al-Syathiby dalam al-Muwafaqat fi Ushul al-Syari'ah bahwa salah satu tujuan tersebut bersifat kebutuhan (hajjiyyah), yaitu segala yang diperlukan oleh manusia untuk menghindarkan diri dari kesulitan, guna menghilangkan kepicikan. Dengan melihat melihat fakta dan realitas yang berkembang pada era sekarang serta atas dasar kemaslahatan, hukum larangan pernikahan antara laki-laki muslim dengan wanita nonmuslim merupakan satu hal yang dapat dipertimbangkan kembali.
\end{abstract}

Kerword: nikah, kitabiyat, Ikhtilaf al-hukmi, Asbab al-Nuzul

\section{PENDAHULUAN}

\section{A. Latar Belakang Masalah}

Pernikahan merupakan salah satu hal yang niscaya bagi setiap manusia. Diciptakannya manusian secara berpasang-pasangan, sebagaimana yang difirmankan oleh Allah dalam Al-Qur'an ${ }^{1}$, merupakan salah satu dari janji-janji Allah yang akan ditepati-Nya. Kesempurnaan Al-Qur'an dalam isinya, menyebabkan aturan-aturan yang ada di dalam Al-Qur'an tidak terhenti dari beberapa ayat yang meniscayakan manusia diciptakan berpasang-pasangan, melainkan hal-hal di luar itu juga diaturnya. Sebut saja Q.S. al-Baqarah [2]: 221, bagaimana Allah dalam ayat itu mengatur hubungan pernikahan antara umat Islam dengan non-Islam.

Tidak berhenti hanya pada tataran ayat saja, para ahli ilmu dan ahl al-mufassirin mencoba menggali pemahaman untuk bisa menyuarakan kebisuan Q.S. al-Baqarah ayat 221 tersebut. Hingga pada akhirnya, interpretasi-interpretasi bermunculan di mana-mana. Ikhtilaf al-hukmi tidak bisa dihindarkan dari istinbat al-hukm yang dilakukan oleh ulama. Maka muncullah satu poin penting yang dihasilkan oleh para ulama mutaqaddimin (walaupun ada beberapa ulama dari golongan muaakhirin) yang membolehkan menikah dengan non-Islam dengan syarat agama yang dipeluknya adalah agama kitabiyat (ahlul kitab).

Namun, tentu apa yang menjadi perhatian para ulama tersebut, konteksnya berbeda dengan yang terjadi pada saat ini, antara kitabiyat klasik dengan kitabiyat abad milenium. Hal ini, memaksa penulis untuk kembali membuka lembaran-lembaran klasik, kembali mempe-rbincangkan wacana tersebut dengan melihat fakta kekinian, dengan berlandaskan satu tujuan, yaitu berusaha me-rekontekstualisasikan teks yang bisu sejak empat belas abad yang silam. Dengan harapan, ketentuan Allah dalam kitab suci-Nya salihun fi kulli al-zaman

1 Lihat Q.S. Al-Ra'ad [13] :3, Q.S. al-Dzariyyat [51]: 49, Q.S. al-Najm [53]: 45, al-Naba [78]: 8. 
wa al-makan. Amin.

\section{B. Rumusan Masalah}

Dalam penulisan ini, penulis merumuskan beberapa masalah, yaitu:

a. Memahami Q.S. al-Baqarah ayat 221 dengan memahami interpretasi ayat tersebut, apa yang sesungguhnya diinginkan oleh Al-Qur'an dengan turunnya ayat tersebut dengan kembali melihat rangkaian historis yang melatarbelakangi turunnya ayat tersebut?

b. Setelah mengetahui kandungan Q.S. al-Baqarah ayat 221, menurut hemat penulis cukup luas kajiannya, penulis lebih menekankan pembahasan ini pada istinbat hukum "Pernikahan Lintas Agama". Bagaimanakah penilai para ulama dan ahli tafsir serta relevankah pandangan tersebut pada masa kini?

\section{PEMBAHASAN}

\section{A. Tinjauan Ayat Al-Qur'an}

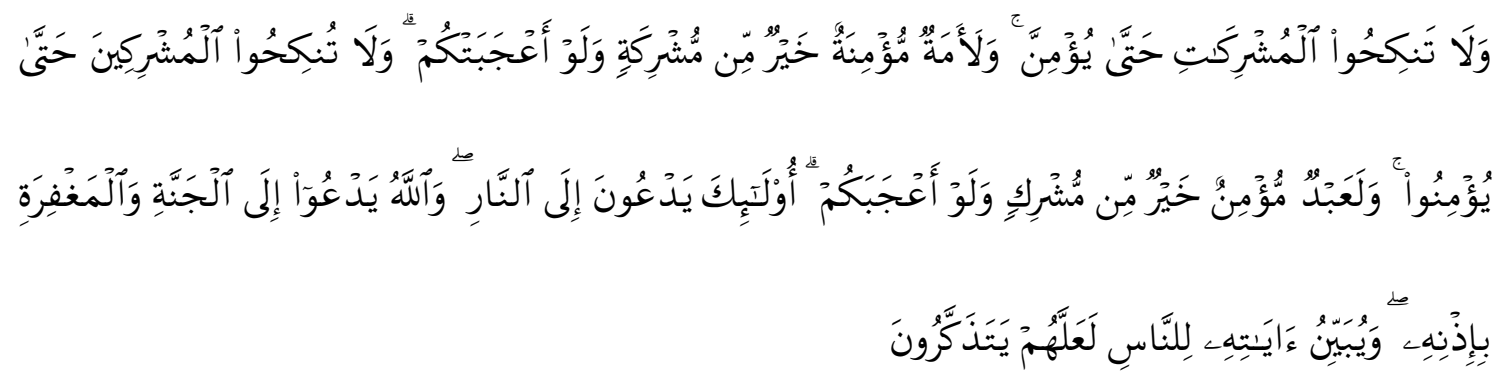

Artinya: "Dan janganlah kamu menikahi wanita-wanita musyrik, sebelum mereka beriman. Sesungguhnya wanita budak yang mukmin lebih baik dari wanita musyrik, walaupun Dia menarik hatimu. dan janganlah kamu menikahkan orang-orang musyrik (dengan wanitawanita mukmin) sebelum mereka beriman. Sesungguhnya budak yang mukmin lebih baik dari orang musyrik, walaupun Dia menarik hatimu. mereka mengajak ke neraka, sedang Allah mengajak ke surga dan ampunan dengan izin-Nya. dan Allah menerangkan ayat-ayatNya (perintah-perintah-Nya) kepada manusia supaya mereka mengambil pelajaran. ${ }^{2}$

Secara sepintas, dapat kita fahami bahwa di dalam ayat tersebut terkandung larangan bagi seorang muslim untuk menikahi wanita-wanita musyrik juga larangan menikah kepada laki-laki musyrik dengan wanita-wanita muslimah. Hal tersebut -seperti yang disuratkan dalam ayat di atas - sekalipun di antara keduanya, musyrik laki-laki maupun perempuan, memiliki penampilan menarik, kaya, golongan bangsawan dan lain sebagainya yang menunjukkan kesempurnaan diri, Al-Qur'an tetap melarang muslim maupun muslimah untuk menikahi orang-orang musyrik.

Permasalahan di atas tentu tidak hanya bisa difahami sekilas dari apa yang tersurat di dalam ayat tersebut. Akan tetapi, jika dikaji lebih mendalam akan ditemui beberapa hal yang menyebabkan Islam melarang keras melakukan pernikahan lintas agama, sebagaimana yang banyak dilakukan oleh orang-orang masa kini. Oleh karenanya, ada beberapa tinjauan berikutnya -melalui asbab al-nuzul, pendekatan sosilogis, serta pemahaman-pemahaman mufassirin yang terekam dalam kitab-kitab tafsir - yang mengantarkan pemahaman kita akan kejelasan ayat tersebut sehingga Islam tidak terkesan anti pluralisme antar agama.

\section{B. Tinjauan Tafsir Mufradat}

Al-Syirk (musyrik-musyrikin-musyrikat), sebagaimana yang dipaparkan oleh M.

2 Al-Qur'an Al-Karim, Quran in word ver 1.3, Q.S. Al-Baqarah [2]: 221. 
Quraish Shihab, ${ }^{3}$ memiliki pandangan yang berbeda antara Al-Qur'an dengan pandangan agama Islam. Syirk adalah mempersekutukan sesuatu dengan sesuatu. Dalam pandangan agama, seorang musyrik adalah siapa yang percaya bahwa ada Tuhan bersama Allah (menyekutukan Allah). Dengan demikian, melalui tinjauan ini semua yang mempersekutukan Allah adalah musyrik. Namun hal berbeda didapat dari para pakar Al-Qur'an, bahwa kata syirk dalam Al-Qur'an tidak demikian maknanya. Al-Qur'an menggunakan kata syirk adalah term yang dikhususkan kepada kelompok tertentu yang mempersekutukan Allah. Mereka adalah para penyembah berhala, yang ketika waktu turunnya Al-Qur'an, masih cukup banyak, khususnya yang bertempat tinggal di Makkah. Dengan demikian, istilah Al-Qur'an berbeda dengan istilah keagamaan di atas. ${ }^{4}$

\section{Tinjauan Asbab al-Nuzul}

Ada beberapa riwayat yang menceritakan latar belakang historis turunnya ayat tersebut, di antaranya:

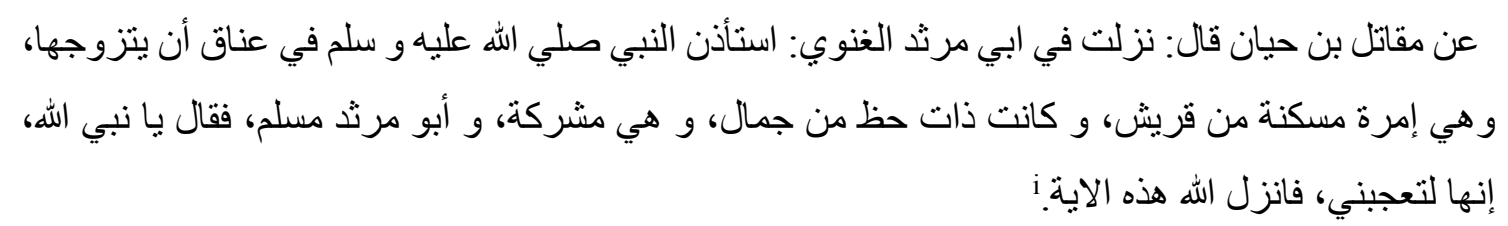

Redaksi lain yang diriwayatkan oleh Abu Daud, an-Nasa'i dan al-Turmudzi menjelaskan bahwa Martsad mau menjemput tawanan orang Islam yang ditangkap oleh orang kafir Quraisy di Makkah. Pada suatu malam ketika hendak menjemput tawanan tersebut, tiba-tiba datang kepada Martsad seorang tunasusila bernama 'Anaq. Ia mendekati Martsad lalu menyapanya. "Bukankah engkau adalah Martsad?" kemudian Martsad menjawab, “ia aku adalah Martsad”. Lalu 'Anaq mengajaknya untuk melakukan zina, tetapi Martsad menolaknya dengan mengatakan "Allah mengharamkan zina”. Kemudian 'Anaq berteriak kencang sehingga menimbulkan reaksi dari orang Quraisy. Melihat keadaan seperti itu Martsad berlari dan masuk dalam sebuah lubang. Dan orang-orang yang mengejar Martsad kemudian mengencinginya sampai akhirnya mereka pulang. Kemudian Martsad kembali ke pada kawannya dan kembali ke Madinah. Setibanya di Madinah, Martsad menghadap Rasulullah seraya berkata "Ya Rasulullah, bolehkah aku menikahi 'Anaq?". Pertanyaan tersebut diulangnya sampai tiga kali, akan tetapi Rasulullah diam saja higga akhirnya turunlah ayat tersebut. ${ }^{5}$

\section{Tinjauan Tafsir Ayat}

Melihat kandungan ayat di atas, dapat difahami bahwa menikah dengan seseorang yang berbeda agama dilarang menurut Islam. Dalam ayat tersebut dijelaskan bahwa ada larangan kepada laki-laki muslim untuk menikahi wanita musyrik dan juga kepada wanita muslimah untuk menjalin hubungan dengan lelaki musyrik. Akan tetapi, pemahaman yang berbeda datang dari kandungan ayat tersebut apakah dalam ayat di atas kasus larangan

3 M. Quraish Shihab, Tafsir al-Misbah, Juz I (Tanggerang: Lentera Hati, 2005), hal. 473.

4 Hal itu bisa dilihat dari pernyataan al-Qur'an dalam Q.S. Al-Baqarah [2]: 105 dan Q.S. al-Bayyinah [98]: 1. Lihat M. Quraish Shihab, Tafsir al-Misbah, Juz I... hal. 474.

5 Abdul Muta'al al-Jabry, Jarimatu al-Zawaj bi Ghairi Muslimat; Fiqhan wa Siasatan (terj). (Jakarta: PT. Bulan Bintang, 1988), hal. 9. Lihat juga riwayat setema namun redaksi yang berbeda dalam Ahmad Mustafa Al-Maraghi, Tafsir al-Maraghi, Juz II, (Beirut: Dar al-Kitab al-Ilmiyah, 2006), hal. 312-313. 
menikah dengan orang musyrik terhenti pada ayat itu saja, artinya kandungan hukum dalam ayat tersebut tidak memiliki keterkaitan (ta'alluq) dengan ketetapan hukum lain dalam AlQur'an? ${ }^{6}$

Mengenai hal tersebut, Syaikh Ahmad Mustafa al-Farrad ${ }^{7}$ berpendapat dengan berpegang pada pemahaman Imam Syafi'i, di mana dalam hal ini Imam Syafi'i berpendapat bahwa ada dua pendapat yang berbeda. Pertama. Ada yang berpendapat bahwa ayat tersebut turun berkenaan dengan sekelompok orang orang musyrik Arab penyembah berhala. Allah mengharamkan menikahi kaum perempuan mereka, sebagaimana Dia juga melarang untuk menikahkan kaum lelaki mereka dengan wanita-wanita mukminat. Jika demikian adanya, maka ayat tersebut merupakan ayat permanen yang tidak memiliki kaitan hukum dengan ayat Al-Qur'an lainnya.

Kedua. Ada yang berpendapat bahwa ayat ini turun berkenaan dengan semua kelompok musyrik, kemudian Allah memberikan keringanan (rukhsah), yang membolehkan nikah dengan perempuan-perempuan ahli kitab yang merdeka, sebagaimana Dia menghalalkan sembelihan ahli kitab. ${ }^{8}$ Dengan demikian, kelompok kedua ini berpendapat bahwa dalam ayat tersebut ada pengecualian, di mana ayat tersebut dinasakh dengan turunnya Q.S. Al-Maidah ayat lima yang membolehkan menikahi ahli kitab yang Al-Qur'an menjelaskan bahwa antara musyrikin dengan ahlul kitab berbeda. ${ }^{9}$

Hal berbeda datang dari al-Shabuniy, dalam kitabnya ia menyatakan bahwa bunyi dari nash Q.S. al-Baqarah ayat 221 tersebut tidak mengindikasikan adanya kasus pe-nasakhan hukum, di mana oleh beberapa ulama sering dikait-kaitkan dengan turunnya Q.S. alMaidah ayat lima. Menurutnya, dalam kasus ini apa yang tertera dalam Al-Qur'an adalah bentuk keumuman lafadz namun isinya mengindikasikan kekhususan. ${ }^{10}$ Artinya, bahwa dalam ayat tersebut sekalipun menunjukkan semua orang musyrik, ayat tersebut tidak berlaku bagi orang-orang ahlul kitab.

Al-Qur'an dalam hal ini, menurut Al-Qurtubi, menetapkan beberapa kekhususan dalam ayat tersebut. Beberapa ahlu al-mufassirin sepakat bahwa sekalipun Q.S. Al-Baqarah ayat 221 tidak mengindikasikan adanya pe-nasakh-an, namun ayat tersebut memiliki keterikatan (ta'alluq) dengan Q.S. Al-Maidah ayat lima, di mana dalam ayat tersebut dijelaskan bahwa menikah dengan wanita ahlul kitab merupakan perkara yang dihalalkan oleh Islam. ${ }^{11}$

Senada dengan kelompok yang kedua, Abu al-Fida Isma'il ibn Katsir al-Dimsyaqi berpendapat, bahwa larangan yang ada di dalam ayat tersebut jika yang diinginkan adalah keumuman lafadz, maka jelas bahwa kitabiyah dan wasaniyah juga dilarang untuk dinikahi. Akan tetapi bahwa ayat tersebut dikecualikan oleh Allah dengan diturunkannya Q.S. Al-

6 Keterkaitan tersebut misalnya dengan Q.S. Al-Maidah [5]: 5.

7 Lihat Syaikh Ahmad Musthafa al-Farran, Tafsir al-Imam al-Syafi'i (terj), Jilid I, (jakarta: Al-Mahira, 2008), hal. 353.

8 Ahmad Musthafa al-Farran, Tafsir al-Imam al-Syafi'i Jilid I,... hal. 355.

9 Dalam beberapa literatur kitab tafsir dijelaskan bahwa antara term musyrikin dengan ahlul kitab dibedakan menurut Al-Qur'an. Misalnya dalam penjelasan Imaduddin bin Muhaamad al-Thabary (w. 205 H) di mana beliau menjelaskan bahwa term musyrikin berbeda dengan ahlul kitab bisa dilacak dalam Q.S. al-Baqarah: 105 dan Q.S. al-Bayyinah: 1. Baca Imaduddin bin Muhaamad al-Thabary, Ahkam al-Qur'an, Juz III (Beirut: Dar al-Kutub al-Ilmiyah, 2001), hal. 129-130. Sedangkan M. Ali al-Shabuniy menjelaskan bahwa term musyrikin meliputi Majusi yang menyembah api atau matahari, Shabi’in, Musyrikin, dan beberapa agama di Indonesia yang menyembah patung, berhala atau sejenisnya. Lihat M. Ali al-Shabuniy, Tafsir Ayat alAhkam, Juz I, (Beirut: Dar al-Kitab al-Ilmiyah, 1991), hal. 221.

10 M. Ali al-Shabuniy, Tafsir Ayat al-Ahkam, Juz I... hal. 204.

11 Lihat pembahasan yang dikemukan oleh Al-Qurthubi dalam Al-Qurthubi, al-jami'u li Ahkam al-Qur'an, Juz III, (Kairo: Maktabah al-Shafa, 2005), hal. 66-80. 
Maidah ayat lima “(dan Dihalalkan mangawini) wanita yang menjaga kehormatan diantara wanita-wanita yang beriman dan wanita-wanita yang menjaga kehormatan di antara orangorang yang diberi Al kitab sebelum kamu". ${ }^{12}$

Dalam hal ini, pendapat yang dikemukakan oleh Ibn Katsir bukannya tidak beralasan. Dalam tafsirnya, Ibn Katsir menjelaskan bahwa pendapat tersebut memang diperkuat oleh beberapa atsar dari beberapa sahabat. Ibn katsir memaparkan, Ali Ibn Abu Talhah meriwayatkan dari Ibn Abbas sehubungan dengan firman Allah dalam Q.S. al-Baqarah ayat 221, bahwa ayat tersebut dikecualikan wanita-wanita dari golongan ahlil kitab. ${ }^{13}$

Selain Ibn Abbas, sebut saja Sayyidina Umar, yang sangat memperhatikan masalah menikah dengan orang yang agamanya berbeda. Dalam tafsirnya Ibn Katsir mengutip atsar yang diriwayat dari Abu Kuraib, menceritakan kami (Abu Kuraib) Ibn Idris, telah menceritakn kepada kami al-Silt ibn Bahram, dari Syaqiq yang menceritakan bahwa huzaifah mengawini wanita Yahudi, lalu Umar ra. berkirim surat kepadanya yang mengatakan, "lepaskan dia". Lalu Huzaifah membalas surat tersebut, "apakah engkau menduga kawin dengan dia haram sehingga aku harus melepaskannya?". Umar mengatakan, "aku tidak menduganya haram dikawini, melainkan aku khawatir kalian enggan menikahi wanita-wanita mukminat karena mereka (wanita-wanita ahli kitab). Menurut Ibn Katsir riwayat ini memiliki sanad yang shahih. ${ }^{14}$

Selain riwayat di atas, menurut ibn Katsir, Ibn Jarir juga mengatakan telah menceritakan kepada kami Abdul Rahman al-Masruq, telah menceritakan kepada kami Muhammad ibn Bisyr, telah menceritakan kepada kami Sufyan ibn Sa'ad, dari Yazid ibn Abu Ziyad, dari Zaid ibn Wahb yang menceritakan bahwa Umar ra. pernah berkata:

$$
\text { المسلم يتزوج النصر انية ولا يتزوج النصر اني المسلمة }
$$

Artinya: "Lelaki muslim boleh mengawini wanita Nasrani, tetapi lelaki Nasrani tidak boleh menikah dengan wanita muslimah". Riwayat ini menurut Ibn Katsir lebih shahih dari pada riwayat yang pertama di atas. ${ }^{15}$

Dengan demikian, apa yang dipaparkan oleh Ibn Katsir menetapkan satu ketentuan hukum bahwa pernikahan antara orang muslim dengan non-muslim ahlul kitab boleh, dengan ketentuan hanya pihak laki-laki (muslim) yang boleh menikah dengan ahlul kitab, sedangkan untuk wanita (muslimah) tidak diperkenankan. Kesimpulan ini diperkuat oleh pendapatnya al-Shabuniy yang menegaskan dengan ungkapannya:

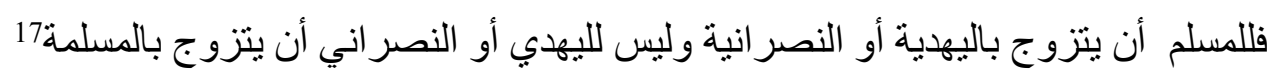

Mengenai pernyataan tersebut, al-Shabuniy berargumen bahwa bolehnya seorang muslim untuk menikahi al-kitabiyah adalah bahwa dalam agama Islam aturan syar'i

12 Ibn Katsir, Tafsir Al-Qur'an al-Karim, Juz I, (Bairut: Dar al-Kutub al-Ilmiyyah, 2006), hal. 247-250.

13 Ibn Katsir, Tafsir Al-Qur'an al-Karim, Juz I, (Bairut: Dar al-Kutub al-Ilmiyyah, 2006), hal. 247-250. Riwayat yang sama juga disampaikan oleh mujahid, Ikrimah, Sa'id ibn Jubair, al-Hasan, al-Dahhak, Zaid ibn Aslam, ar-rabi ibn Anas. Liat Ibn Katsir, Tafsir Al-Qur'an al-Karim, (Bairut: Dar al-Kutub al-Ilmiyyah, 2006), hal. 247-250.

14 Ibn Katsir, Tafsir Al-Qur'an al-Karim, Juz I... hal. 247-250.

15 Ibn Katsir, Tafsir Al-Qur'an al-Karim, Juz I... hal. 247-250. 
mewajibkan kepada para kaum muslimin untuk memuliakan Nabi Musa dan Isa, mengimani risalahnya, meyakini kitab Taurat dan Injil diturunkan pada mereka berdua. Oleh sebabnya, jika seorang muslim menikahi kitabiyah, sang suami tidak akan melanggar akidah sang istri. Berbeda misalnya jika sang suami yang kitabiyyi, sedangkan istrinya adalah muslimah, maka akan dikhawatirkan ada pelanggaran-pelanggaran etika akidah, karena sebagaimana yang kita ketahui bersama istri wajib tunduk pada suami. ${ }^{16}$

\section{E. Tinjauan Analisis-Kritis}

Al-Qur'an yang diturunkan kurang lebih 14 abad silam, menyisakan permasalahanpermasalah kekinian yang perlu dilihat kerelevansian fakta historis pada saat ayat tersebut turun, agar teks yang ada di dalam Al-Qur'an tidak lagi bisu (baca: memuat hukum statis). Oleh karenanya, mengkaji Al-Qur'an secara mendalam dan komperehensip serta mampu mengaktualisasikannya pada masa kini, merupakan hal yang niscaya. Hingga pada akhirnya, kandungan-kandungan hukum Al-Qur'an sesuai dengan harapan shalih fi kulli zaman wa makan. Hal ini tidak menjadi pengecualian Q.S. Al-Baqarah ayat 221, di mana dalam uraian penafsiran ayat yang telah dikemukan, ada beberapa pendapat mengenai status hukum ayat tersebut.

Ketetapan hukum yang telah disepakati hampi oleh jumhur al-mufassirin, membuahkan poin penting bahwa pernikahan antara laki-laki muslim dengan non-muslim ahlul kitab diperbolehkan, sedangkan antara wanita muslimah dengan pria non-muslim sekalipun ahlul kitab tidak diperkenankan. Satu poin penting ini, kiranya merupakan satu kajian yang menarik untuk kembali dianalisis dengan kaca mata kemaslahatan umat serta melalui pendekatan maqasyid al-syari'ah.

Berangkat dari fakta yang ada, Al-Maghari dalam tafsirnya, meperlihatkan pada kita bagaimana realitas masyarakat Mesir tentang nikah berlainan agama ini. Di mana sebagian besar pemuda Mesir lebih memilih menikah dengan orang Asing, sehingga mereka cenderung mengabaikan wanita muslimah, mukminah lagi suci. Lebih lanjut Al-Maghari mengatakan, akibat yang ditimbulkan adalah rusaknya agama dan nilai kebangsaan mereka, hubungan suami dengan keluarganya menjadi terputus, sehingga banyak di antara mereka yang memilih untuk mentalaq istrinya. Jika mereka, ingin tetap mempertahankan pernikahan, maka mereka harus mempermalukan diri mereka (memasuki agama sang wanita. pen). Karena sangat sedikit wanita non-Islam yang setelah menikah memilih untuk masuk agama Islam. ${ }^{17}$

Tentu apa yang dikemukan oleh Ibn Katsir bahwa beberapa riwayat dengan jalur sanad yang shahih, menguatkan satu statement besar bahwa tidak ada riwayat yang secara tegas menyatakan larangan menikah -dalam konteks ini adalah laki-laki muslim dengan non-muslim dari ahlul kitab karena hukum sebaliknya, pernikahan antara wanita muslimah dengan laki-laki non muslim jelas keharamannya - dengan orang yang berbeda agama. Memperhatikan dengan seksama, kiranya ada satu riwayat asar yang disandarkan kepada Sayyidina Umar, yang perlu untuk kita lihat kembali kandungan isinya dengan melihat pada fakta dan realitas di atas. Imam Al-Bukhari (w. 256 H) meriwayatkan sebuar asar, yaitu:

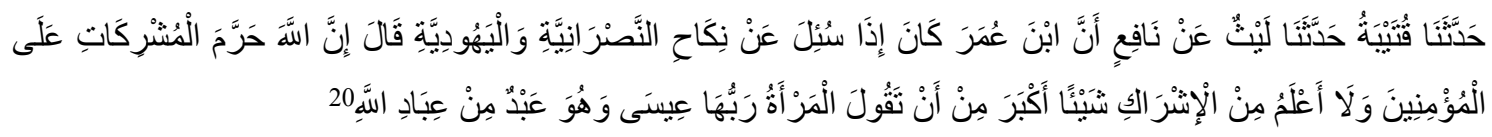

16 M. Ali al-Shabuniy, Tafsir Ayat al-Ahkam, Juz I... hal. 205.

17 Ahmad Mustafa Al-Maraghi, Tafsir al-Maraghi, Juz II, (Bairut; Dar al-Kutub al-Ilmiyah, 2006), hal. 315. 
Artinya: "Telah menceritakan kepada kami Qutaibah Telah menceritakan kepada kami Laits dari Nafi> bahwa apabila Ibnu Umar ditanya tentang hukum menikahi wanita Nashrani dan wanita Yahudi ia menjawab, "Sesungguhnya Allah telah mengharamkan wanita-wanita musyrik atas orang-orang yang beriman. Dan aku tidak mengetahui adanya kesyirikan yang paling besar daripada seorang wanita yang mengatakan bahwa Rabbnya adalah Isa, padahal ia hanyalah hamba dari hamba-hamba Allah.» Riwayat ini juga tidak kalah shahih $^{18}$-nya dengan riwayat yang digunakan oleh Ibn Katsir di atas.

Melihat fakta yang diuraikan oleh al-Maghari serta melihat asar yang berbeda sudut pandang, hemat penulis, memandang hukum pernikahan antara laki-laki muslim dengan wanita non-muslim dari sisi maslahat menjadi hal yang urgen untuk rekontekstualisasi teks Al-Qur' an yang bisu sejak empat belas abad yang silam. Di mana pada akhirnya, poin yang bisa disimpulkan adalah tidak boleh adanya pernikahan antara orang Islam dengan orang non-Islam. ${ }^{19}$

Hemat penulis, ketetapan hukum tersebut lebih mendekati tujuan yang diinginkan syari'at (maqashid al-Syar'i), di mana salah satu poin dalam maqashid al-Syar'i adalah hifdz al-nasab. Dengan kembali menimbang, bahwa maqashid al-Syariah sebagai tujuan yang dikehendaki oleh syari'at, sebagaimana pernyataan Al-Syathiby dalam al-Muwafaqat fi Ushul al-Syari'ah yang dikutip oleh Tarmizi M. Jakfar, ${ }^{20}$ salah satu tujuan tersebut bersifat kebutuhan (hajjiyyah), yaitu segala yang diperlukan oleh manusia untuk menghindarkan diri dari kesulitan, guna menghilangkan kepicikan. Dengan melihat tujuan ini dan -kembali penulis tegaskan - melihat fakta dan realitas yang berkembang pada era sekarang serta atas dasar kemaslahatan, hemat penulis, hukum larangan pernikahan antara laki-laki muslim dengan wanita non-muslim merupakan satu hal yang bisa untuk kembali dipertimbangkan.

18 Perawi yang ada tersebut, dari Qutaibah, yang bernama lengkap Qutaibah bin Sa'id bin Jamil bin Tharif bin Abdullah (w. 240 H) berpredikat Tsiqah menurut Abu Hatim dan An-Nasa'i. Laits, yang bernama lengkap Laits bin Sa'ad bin Abdur Rahman (w. 175 H) yang berpredikat Tsiqah menurut Yahya bin Ma'in. Sedangkan yang terakhir adalah Nafi', yang bernama lengkap Nafi', maula Ibnu 'Umar" (w. 117 H) dengan predikat Tsiqah menurut Ibn Kharasy. Lihat Lidwa Pusaka, Ensiklopedi Hadis Kitab 9 Imam (Kitabu al-Tis'ah); Sahih Bukhari Kitab al-Thalaq no. 4877, Ver. 2010.

19 Lihat M. Quraish Shihab, Tafsir al-Misbah, Juz I, (Tanggerang: Lentera Hati, 2005), hal. 477. Namun dalam hal ini, penulis berbeda pendapat dengan Quraish Shihab yang masih memberikan celah dari kesimpulan hukumnya. Dimana setelah menetapkan “ke-tidakboleh-an' terjadinya pernikahan antara laki-laki muslim dengan wanita non-muslim, beliau memberikan satu solusi hukum dengan kata "paling tidak hukumnya makruh" jika terjadi pernikahan antara laki-laki muslim dengan wanita non-muslim.

20 Lengkapnya, menurut kutipan Tarmizi M. Jakfar, setidaknya tujuan tersebut ada tiga. Pertama. Tujuan yang sifatnya paling utama (dharuriyyah), yaitu segala sesuatu yang harus ada untuk tegaknya kehidupan manusia, baik yang sifatnya agama maupun dunia. Kedua. Tujuan yang sifatnya kebutuhan (hajjiyyah), yaitu segala yang diperlukan oleh manusia untuk menghindarkan diri dari kesulitan, agar tercipta kehidupan yang tentram. Ketiga. Tujuan yang sifatnya kesempurnaan/kebaikan (tahsiniyah), yaitu mempergunakan segala yang layak dan pantas yang dibenarkan oleh adat istiadat yang baik. Lihat Tarmizi m. Jakfar, Otoritas Sunnah Non-Tasyri’iyyah Menurut Yusuf al-Qaradhawi, (Yogyakarta: Ar-Ruz Media, 2011), hal. 29. 
Al-Qur'an Al-Karim

\section{DAFTAR PUSTAKA}

al-Farran, Ahmad Musthafa, Tafsir al-Imam al-Syafi'i (terj), Jilid I, Jakarta: Al-Mahira, 2008.

Al-Jabry, Abdul Muta'al, Jarimatu al-Zawaj bi Ghairi Muslimat; Fiqhan wa Siasatan (terj), Jakarta: PT. Bulan Bintang, 1988.

Al-Maraghi, Ahmad Mustafa, Tafsir al-Maraghi, Bairut: Dar al-Kutub al-Ilmiyyah, 2006.

Al-Shabuny, M. Ali, Tafsir Ayat al-Ahkam, Juz I, Bairut: Dar al-Kitab al-Ilmiyyah, 1991.

Al-Nasaibury, Al-Imam al-Wahidi, Asbab al-Nuzul, Bairut: Daar al-Kutub al-Ilmiyyah, 2008 .

Al-Qurthubi, al-Jami'u li Ahkam al-Qur'an, Juz III, Kairo: Maktabah al-Shafa, 2005.

Al-Thabary, Ahkam al-Qur'an, Juz III, Bairut: Dar al-Kutub al-Ilmiyah, 2001.

Ibn Katsir, Tafsir Al-Qur'an al-Karim, Bairut, Dar al-Kutub al-Ilmiyyah, 2006.

Imam al-Shawi, Tafsir Hasyiatu al-Shawi,Bairut: Dar al-Fikr, 1993.

Jakfar, Tarmizi M., Otoritas Sunnah Non-Tasyri'iyyah Menurut Yusuf al-Qaradhawi, Yogyakarta: Ar-Ruz Media, 2011.

Lidwa Pusaka, Ensiklopedi Hadis Kitab 9 Imam (Kitabu al-Tis'ah), Ver. 2010.

Quraish, M. Shihab, Tafsir al-Misbah, Juz I, Tanggerang: Lentera Hati, 2005. 